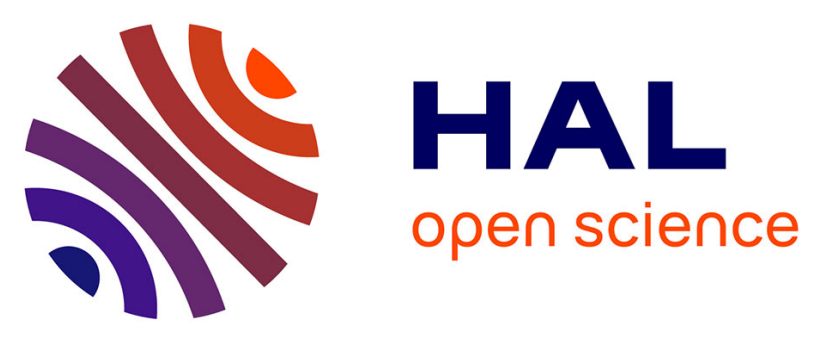

\title{
Long-term Cu stabilization and biomass yields of Giant reed and poplar after adding a biochar, alone or with iron grit, into a contaminated soil from a wood preservation site
}

Nadège Oustriere, Lilian Marchand, Nathalie Lottier, Mikael Motelica-Heino, Michel Mench

\section{To cite this version:}

Nadège Oustriere, Lilian Marchand, Nathalie Lottier, Mikael Motelica-Heino, Michel Mench. Longterm $\mathrm{Cu}$ stabilization and biomass yields of Giant reed and poplar after adding a biochar, alone or with iron grit, into a contaminated soil from a wood preservation site. Science of the Total Environment, 2017, 579, pp.620-627. 10.1016/j.scitotenv.2016.11.048 . insu-01414495

\section{HAL Id: insu-01414495 \\ https://hal-insu.archives-ouvertes.fr/insu-01414495}

Submitted on 12 Dec 2016

HAL is a multi-disciplinary open access archive for the deposit and dissemination of scientific research documents, whether they are published or not. The documents may come from teaching and research institutions in France or abroad, or from public or private research centers.
L'archive ouverte pluridisciplinaire HAL, est destinée au dépôt et à la diffusion de documents scientifiques de niveau recherche, publiés ou non, émanant des établissements d'enseignement et de recherche français ou étrangers, des laboratoires publics ou privés.

\section{(ㅇ)(1) $\$$}

Distributed under a Creative Commons Attribution - NonCommercial - NoDerivatives $\mid 4.0$ 


\title{
Long-term Cu stabilization and biomass yields of Giant reed and poplar after adding a biochar, alone or with iron grit, into a contaminated soil from a wood preservation site
}

\author{
Nadège Oustriere $^{\mathrm{a}, *}$, Lilian Marchand $^{\mathrm{a}}$, Nathalie Lottier ${ }^{\mathrm{b}}$, Mikael Motelica ${ }^{\mathrm{b}}$, Michel Mench ${ }^{\mathrm{a}}$ \\ a BIOGECO, INRA, Univ. Bordeaux, 33615 Pessac, France \\ b ISTO UMR 7327-CNRS, University of Orléans, Campus Géosciences, 1A, rue de la ferollerie, 45071 Orléans cedex 2, France
}

\section{H I G H L I G H T S}

- Biochar with and without iron grit was added in a Cu-contaminated soil.

- Soil pore water: biochar with iron grit reduced its $\mathrm{Cu}^{2+}$ and $\mathrm{Cu}$ contents in year 2

- Both amendments did not improve Giant reed and poplar growth.

- Shoot Cu concentration of poplar and Giant reed reached common values.

- Giant reed can increase the potential $\mathrm{Cu}$ leaching out of the root-zone.
GRAPHICALA B T RACT

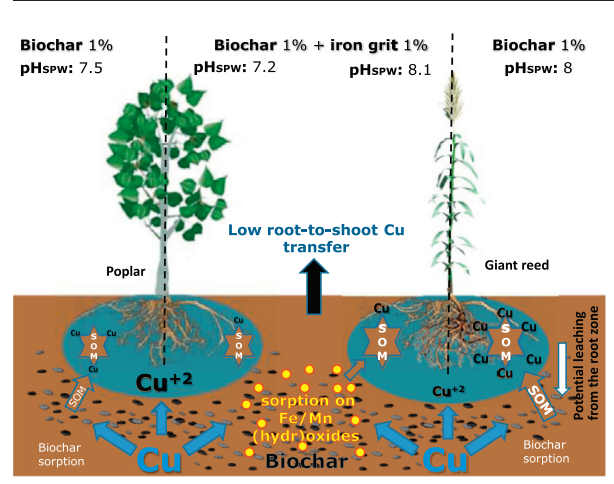

\section{Keywords:}

Arundo donax L.

Populus nigra L.

Soil pore water

Copper contamination

In situ stabilization

Phytomanagement

\begin{abstract}
A B S T R A C T
A 2-year pot experiment was carried out to examine the aging effect of biochar (B), alone or combined with iron grit (Z), on Cu stabilization and plant growth in a contaminated soil $\left(964 \mathrm{mg} \mathrm{Cu} \mathrm{kg}^{-1}\right)$ from a wood preservation site. The experiment consisted in 3 soil treatments, either planted with Arundo donax L. (Ad) or Populus nigra L. $(P n)$ : (1) untreated Cu-contaminated soil $(A d, P n)$; (2) Unt $+1 \%(\mathrm{w} / \mathrm{w}) \mathrm{B}(A d \mathrm{~B}, P n \mathrm{~B})$, and $(3)$ Unt $+1 \%$ $\mathrm{B}+1 \% \mathrm{Z}$ (AdBZ, PnBZ). After 22 months, the soil pore water (SPW) was sampled and roots and shoots were harvested. The SPW compositions at 3 and 22 months were compared, showing that the SPW $\mathrm{Cu}^{2+}$ concentration increased again in the PnB and PnBZ soils. Cultivation of A. donax enhanced the dissolved organic matter concentration in the SPW, which decreased its $\mathrm{Cu}^{2+}$ concentration but promoted its total $\mathrm{Cu}$ concentration in the $\mathrm{Ad}$ and $A d B$ soils. Adding $\mathrm{Z}$ with $\mathrm{B}$ reduced both SPW $\mathrm{Cu}^{2+}$ and $\mathrm{Cu}$ concentrations in the pots cultivated by $A$. donax and $P$. nigra as compared to B alone. The B and BZ treatments did not enhance root and shoot yields of both plant species as compared to the Unt soil but their shoot $\mathrm{Cu}$ concentrations were in the range of common values.
\end{abstract}

\section{Introduction}

* Corresponding author.

E-mail addresses: oustriere.nadege@gmail.com (N. Oustriere), marchand.lilian@gmail.com (L. Marchand), nathalie.lottier@univ-orleans.fr (N. Lottier), mikael.motelica@univ-orleans.fr (M. Motelica), michel.mench@inra.fr (M. Mench).
Soil Cu contamination at wood preservation sites frequently resulted from long-term use of Cu-based salts as wood preservatives and wood washings (Bes and Mench, 2008; Oustriere et al., 2016a). The 
functioning of ecosystems associated with such Cu-contaminated soils is generally affected, due to soil ecotoxicity and Cu dispersion through natural agencies (Bakshi et al., 2014).

Out of gentle options for remediating $\mathrm{Cu}$-contaminated soils, in situ stabilization is an alternative to physico-chemical methods. It aims at reducing the pollutant linkages by managing the contaminant pathways to protect the biological receptors (Cundy et al., 2015). It relies on incorporation of amendments into the soil to immobilize metal(loid)s in the stable solid phase by sorption, precipitation, complexation, ion exchange or redox process, thereby decreasing their mobility and bioavailability (Kumpiene et al., 2008; Bolan et al., 2014). Amending soils with biochar can (1) increase the cation exchange capacity (CEC), pH, and retention of water and nutrients, (2) improve microbial soil habitats and (3) immobilize contaminants (Zhang et al., 2013). Several studies have assessed the biochar effectiveness for in situ stabilization of $\mathrm{Cu}$ contaminated soils (Beesley and Marmiroli, 2011; Beesley et al., 2011). As suggested by Beesley and Marmiroli (2011), combining amendments with biochar may be more efficient than biochar alone for the remediation and revegetation of contaminated soils. Iron grit mainly consists of zerovalent $\mathrm{Fe}(0)$ and $\mathrm{Mn}$ and rapidly corrodes into the soil to form newly Fe/Mn oxi(hydro)xides. Such (hydro)xides can sorb metal(loid)s and reduce their (bio)availability (Kumpiene et al., 2011; Tiberg et al., 2016). In a previous pot experiment, a pine barkderived biochar $(1 \% \mathrm{w} / \mathrm{w})$ decreased $\mathrm{Cu}^{2+}$ concentration in the soil pore water (SPW) of a contaminated soil ( $964 \mathrm{mg} \mathrm{Cu} \mathrm{kg}^{-1}$ ) from a wood preservation site (Oustriere et al., 2016a). Adding this biochar with iron grit $(1 \% \mathrm{w} / \mathrm{w})$ decreased both total $\mathrm{Cu}$ and $\mathrm{Cu}^{2+}$ concentrations in the SPW. However biochar alone and in combination did not promote the growth of dwarf bean (Phaseolus vulgaris L.). Moreover this study was limited to a 3-month reaction period followed by a 2week plant testing. Potential changes in the phytotoxicity of biocharamended soils over time must be considered. Long-term efficiency of soil amendments is pivotal to sustain metal(loid) immobilization in contaminated soils and to avoid their leaching out of the root zone.

Few long-term studies reported an increased immobilization of trace elements (TE) over time in biochar-amended soils (Cd, Pb: Bian et al., 2014; Ni, Zn: Shen et al., 2016). Such long-term effects on TE immobilization however depend on biochar and soil types. After 3 years, hardwoodderived biochar gradually reduced the $\left(\mathrm{CaCl}_{2}\right)$-extractable $\mathrm{Cd}$ and $\mathrm{Cu}$ concentrations and uptake by rice, while these values did not change in the soil amended by corn-straw-derived biochar (Li et al., 2016). Eucalyptus wood-derived-biochar aged for 12 months into two (Cd/As)spiked soils increased $\mathrm{Cd}$ and As sorption in the Inceptisol whereas it decreased As sorption in the Oxisol (Nagodavithane et al., 2014). The sorption capacity of aged biochar may depend on (1) metal(loid)s, (2) SPW pH, and (3) soil properties such as organic matter (OM) content and oxidation process through both abiotic and biotic mechanisms (Nagodavithane et al., 2014).

Among energy crops, poplar (Populus sp.,) and Giant reed (Arundo donax L.) used in short rotation coppices (SRC) have been tested for producing valuable feedstock for bioenergy productions on contaminated soils (Lucas-Borja et al., 2011; Evangelou et al., 2012; Kidd et al., 2015; Mola-Yudego et al., 2015; Gonsalvesh et al., 2016). The lignocellulosic biomass of such plants can be either used to produce heat and electricity by direct combustion, transformed by pyrolysis and gasification into biofuels and biochars or used for producing derived bioproducts notably platform chemicals (Bridgwater, 2006; Nsanganwimana et al., 2014). Poplar is a fast growing tree, producing large yields, tolerant to high TE exposures, with low contaminant accumulation in the wood $(\mathrm{Cd} /$ $\mathrm{Zn}$ are mainly accumulated in the leaves) and having high energy potential (Calfapietra et al., 2010). Arundo donax is a productive species, highly stress resilient (e.g. cold, drought, salinity, and extreme $\mathrm{pH}$ ) (Mantineo et al., 2009), tolerant to high TE exposure (Elhawat et al., 2015), usable by many conversion chains, e.g. energy sector, litter, pulp and building materials (Scordia et al., 2012; Nsanganwimana et al., 2014).
In situ stabilization combined with either Populus nigra L. or A. donax cultivation is a potential option to produce a valuable biomass while stabilizing Cu-contaminated soils at wood preservation sites. Therefore, we investigated the long-term aging effect of biochar, alone and combined with iron grit, in such Cu-contaminated soil cultivated with both plant species through (1) $\mathrm{Cu}$ and nutrient concentrations in the soil pore water, (2) biomass production of $P$. nigra and A. donax, and (3) shoot $\mathrm{Cu}$ concentrations and removals.

\section{Material and methods}

\subsection{Soil, amendments and soil treatments}

The wood preservation site (about 10 ha, Saint-Médard d'Eyrans, Gironde, SW France; $44^{\circ} 43.353^{\prime} \mathrm{N}, 000^{\circ} 30.938^{\prime} \mathrm{W}$ ) has been used for over a century, with various Cu-based salts (mainly Cu-sulphate based on the duration and amount used) as wood preservatives (Mench and Bes, 2009). Topsoil (Unt, 0-25 cm, Fluvisol - Eutric Gleysol, World Reference Base for soil resources) was collected $(100 \mathrm{~kg}$ ) at the P1-3 sub-site. This sandy soil ( $85.8 \%$ sand, $5.9 \%$ clay, and $8.3 \%$ silt; $1.3 \% \mathrm{OM}$; C/N 16 ), with a low CEC, is mainly contaminated by Cu (Table 1, Oustriere et al., 2016a), which largely exceeds its median and upper whisker background values in French sandy soils, but its total soil As and $\mathrm{Cr}$ are at background levels (Table 1, Baize, 2000; Villanneau et al., 2008). Soil was air-dried and homogenized after sieving through a $5 \mathrm{~mm}$ mesh.

Two treatments, a pine bark-derived biochar (B, pyrolysis of $420{ }^{\circ} \mathrm{C}$ for $180 \mathrm{~s}$; not desalted; Florentaise, Saint-Mars-du-Désert, France) alone and combined with zerovalent iron grit (BZ), were trialed. Biochar was crushed, sieved at $2 \mathrm{~mm}$ and manually homogenized. Elemental composition, carbon (C) content and polycyclic aromatic hydrocarbon (PAH) concentrations were determined at the INRA Laboratoire d'Analyses des Sols (INRA LAS, Arras, France) with standard methods (Table 2). Zerovalent iron grit (Z, GH120, particle size $<0.1 \mathrm{~mm}$ ) was obtained from Wheelabrator Allevard, France (Bes and Mench, 2008). Amended soils were thoroughly homogenized in large plastic containers and individually prepared prior to use.

The pot experiment consisted in 3 soil treatments: (1) untreated Cucontaminated soil (Unt); (\%, w/w) (2) Unt + 1\% B (B), (3) Unt $+1 \%$ $\mathrm{B}+1 \% \mathrm{Z}$ (BZ). Each treatment was made in 10 replicates. Soils (3 kg) were potted ( $5 \mathrm{~L}$, plastic pots) and placed in a greenhouse. Potted soils, with a bottom cup to avoid any leaching, were watered and weekly maintained to $70 \%$ of water holding capacity (WHC, $10 \%$ of air-dried

Table 1

Main physico-chemical soil parameters.

\begin{tabular}{lll}
\hline Parameter & Mean $\pm \mathrm{SD}$ & Background levels $^{\mathrm{a}}$ \\
\hline $\mathrm{pH}$ & $7 \pm 0.09$ & 6.6 \\
$\mathrm{CEC}$ & $2.5 \pm 0.2$ & \\
$\mathrm{P}_{2} \mathrm{O}_{5}\left(\mathrm{~g} \mathrm{~kg}^{-1}\right)$ & $0.03 \pm 0.002$ & \\
Organic matter $\left(\mathrm{g} \mathrm{kg}^{-1}\right)$ & $13 \pm 0.4$ & 14.5 \\
Organic C $\left(\mathrm{g} \mathrm{kg}^{-1}\right)$ & $8 \pm 0.3$ & \\
Total N $\left(\mathrm{g} \mathrm{kg}^{-1}\right)$ & $0.5 \pm 0.01$ & 10 \\
$\mathrm{C} / \mathrm{N}$ & $16 \pm 0.2$ & \\
Texture $\left(\mathrm{g} \mathrm{kg}^{-\mathbf{1}}\right)$ & & $\geq 650$ \\
Sand & 858 & $\leq 350$ \\
Silt & 83 & $\leq 180$ \\
Clay & 59 & \\
Total TE $\left(\mathbf{m g ~ k g}^{-\mathbf{1}}\right)$ & & $14-40$ \\
$\mathrm{Cr}$ & $21 \pm 0.7$ & $3.2-8.4$ \\
$\mathrm{Cu}$ & $964 \pm 20$ & $4.2-14.5$ \\
$\mathrm{Ni}$ & $5 \pm 0.3$ & $17-48$ \\
$\mathrm{Zn}$ & $37 \pm 1.6$ & $1-25^{\mathrm{b}}$ \\
$\mathrm{As}$ & $7 \pm 0.4$ & $2000 ; \mathrm{Vil}$ \\
\hline
\end{tabular}

a Frequent total concentrations in French sandy topsoils (Baize, 2000; Villanneau et al., 2008).

b Frequent total As concentrations for all French soil types (Bes and Mench, 2008). 


\begin{tabular}{|c|c|c|c|c|c|}
\hline & B & $\mathrm{Z}$ & $\mathrm{EBC}^{\mathrm{a}}$ & $\mathrm{IBI}^{\mathrm{b}}$ & $\begin{array}{l}\text { French upper } \\
\text { critical threshold } \\
\text { values for organic } \\
\text { amendments }^{c}\end{array}$ \\
\hline $\mathrm{pH}$ & 9.89 & & - & - & \\
\hline $\mathrm{CEC}\left(\mathrm{cmol} \mathrm{kg}^{-1}\right)$ & 1.23 & & - & - & \\
\hline \multicolumn{6}{|l|}{ Major elements (\% DW) } \\
\hline $\mathrm{H}$ & 0.8 & & - & - & \\
\hline $\mathrm{N}$ & 0.3 & & - & - & \\
\hline S & 0.03 & & - & - & \\
\hline $\mathrm{Cl}$ & 0.01 & & - & - & \\
\hline \multirow[t]{6}{*}{ C } & 90.3 & & $>$ & Class 1: $\geq$ & \\
\hline & & & $50 \%$ & $60 \%$ & \\
\hline & & & & Class 2: & \\
\hline & & & & [30\% - 60\%] & \\
\hline & & & & $\begin{array}{l}\text { Class 3: } \\
{[10 \%-30]}\end{array}$ & \\
\hline & & & & & \\
\hline \multicolumn{6}{|l|}{ Nutrients $\left(\mathrm{g} \mathrm{kg}^{-1}\right)$} \\
\hline $\mathrm{Ca}$ & 18.6 & & - & - & \\
\hline K & 13.8 & & - & - & \\
\hline $\mathrm{Mg}$ & 29.9 & & - & - & \\
\hline $\mathrm{Na}$ & 0.389 & & - & - & \\
\hline $\mathrm{P}$ & 0.105 & & - & - & \\
\hline \multicolumn{6}{|l|}{ Elements $\left(\mathrm{mg} \mathrm{kg}^{-1}\right)$} \\
\hline $\mathrm{Al}$ & 1650 & 600 & - & - & \\
\hline As & 0.461 & 70 & - & $12-100$ & 18 \\
\hline $\mathrm{Cd}$ & $<0.5$ & 0.03 & 1 & $1.4-39$ & 3 \\
\hline $\mathrm{Cr}$ & 45.9 & 3500 & 80 & $64-1200$ & 300 \\
\hline $\mathrm{Cu}$ & 230 & 1010 & 100 & $63-1500$ & 120 \\
\hline Mn & - & 7710 & - & - & \\
\hline $\mathrm{Fe}$ & 4470 & 973,000 & - & - & \\
\hline $\mathrm{Hg}$ & $<0.1$ & & 1 & $1-17$ & 2 \\
\hline $\mathrm{Ni}$ & 28.3 & 739 & 30 & $47-600$ & 60 \\
\hline $\mathrm{Pb}$ & 2.61 & 20 & 120 & $70-500$ & 180 \\
\hline $\mathrm{Zn}$ & 50.5 & 104 & 400 & $200-7000$ & 600 \\
\hline \multicolumn{6}{|l|}{ PAHs (mg kg ${ }^{-1}$ ) } \\
\hline $\begin{array}{l}\text { Sum of } 16 \text { US EPA } \\
\text { PAHs }^{\mathrm{d}}\end{array}$ & 163 & & 4 & $6-300$ & \\
\hline Fluoranthene & 7.48 & & - & - & 4 \\
\hline Benzo(b)fluoranthene & 0.149 & & - & - & 2.5 \\
\hline Benzo(a)pyrene & $<0.2$ & & - & - & 1.5 \\
\hline Naphtalene & 101 & & - & - & \\
\hline
\end{tabular}

a Following Switzerland's Chemical Risk Reduction Act (ChemRRV) on recycling fertilizers.

b Range of Maximum Allowed Threshold values reflects different soil tolerance levels for these elements in compost, biosolids, or soils established by regulatory bodies in the US, Canada, EU and Australia (See Appendix 3 of the IBI Biochar Standards for further information).

c French upper critical threshold values for organic amendments (NF U 44 051, Dec. 2010).

d Corresponds to the PAH threshold values defined in the Swiss Chemical Risk Reduction Act (Chem RRV).

soil) with deionized water, and allowed to react for one month in May 2014. Thereafter, plant was cultivated from June 2014 to March 2016.

\subsection{Plant testing}

Stem cuttings of $P$. nigra and Giant reed (A. donax) (roughly $20 \mathrm{~cm}$ long) were collected in May 2013. Poplars were sampled on 4-year old trees growing at this wood preservation site. Giant reed plants were sampled from natural stand along a drainage ditch, San Remo, Italy, and cultivated since 2012 in a greenhouse. Stem cuttings were rooted in individual pots $\left(9 * 8 * 9 \mathrm{~cm}^{3}\right)$ on perlite imbibed with a quarter-strength Hoagland nutrient solution (HNS, Marchand et al., 2014) for one year in a greenhouse. For each treatment, one standardized plant of either P. nigra or A. donax was transplanted in potted

soils (five replicates) and cultivated during 22 months from June 2014 to March 2016 in a greenhouse. The experiment consisted in 6 treatments:

(1) untreated Cu-contaminated soil planted with P. nigra (Pn)

(2) B-amended soil planted with P. nigra $(P n B)$

(3) BZ-amended soil planted with P. nigra (PnBZ)

(4) untreated Cu-contaminated soil planted with A. donax (Ad)

(5) B-amended soil planted with A. donax (AdB)

(6) BZ-amended soil planted with A. donax (AdBZ).

Pots were arranged in a fully randomized block and maintained at $70 \%$ of WHC using deionized water without loss from drainage. Hoagland nutrient solution $(250 \mathrm{~mL}$ ) was applied each month in all pots to avoid nutrient deficiencies. Before the beginning of the 2015 growing season, in March, dry shoots of A. donax were harvested (Cut 1), $1 \mathrm{~cm}$ above the soil surface. In March 2016, the shoots and roots of P. nigra (Cut 1) and A. donax (Cut 2) were harvested. All harvested biomass were washed twice with deionized water, blotted with filter paper, placed in paper bags and oven dried at $60{ }^{\circ} \mathrm{C}$ to constant weight for $72 \mathrm{~h}$ and then weighed for determining the shoot and root DW yields.

\subsection{Soil pore water and plant analysis}

Dried shoots were ground ( $<1.0 \mathrm{~mm}$ particle size, Retsch MM200) then weighed aliquots $\left(0.5 \mathrm{~g} \mathrm{DW} \mathrm{pot}^{-1}\right)$ were wet digested under microwaves (CEM Marsxpress $1200 \mathrm{~W}$ ) with $5 \mathrm{~mL}$ supra-pure $14 \mathrm{M}$ $\mathrm{HNO}_{3}$ and $2 \mathrm{~mL} 30 \%(v / \mathrm{v}) \mathrm{H}_{2} \mathrm{O}_{2}$ not stabilized by phosphates. Certified reference material (BIPEA maize V463) and blank reagents were included in all series. Mineral composition ( $\mathrm{Al}, \mathrm{B}, \mathrm{Ca}, \mathrm{Cu}, \mathrm{Fe}, \mathrm{Mg}, \mathrm{Mn}, \mathrm{P}, \mathrm{K}, \mathrm{Na}$, and $\mathrm{Zn}$ ) in digests was determined by ICP-MS (Thermo $\mathrm{X}$ series 200) at the INRA USRAVE laboratory, Villenave-d'Ornon, France. All elements were recovered (>95\%) according to the standard values and standard deviation for replicates was $<5 \%$. Shoot $\mathrm{Cu}$ removal was calculated as: $\mathrm{Cu}\left(\mu \mathrm{g}\right.$ plant $\left.{ }^{-1}\right)=$ shoot DW yield $\left(\mathrm{g}_{\text {plant }}{ }^{-1}\right) \mathrm{x}$ shoot $\mathrm{Cu}$ concentration ( $\left.\mu \mathrm{g} \mathrm{g}^{-1} \mathrm{DW}\right)$.

23 months after the soil amendment, the soil pore water (SPW) was collected in all pots just before the harvest of $P$. nigra and A. donax (March 2016, three times $10 \mathrm{~mL}$ ) using Rhizon MOM moister samplers (Eijkelkamp Agrisearch Equipment, The Netherlands) placed in January 2016 and samples kept at $4{ }^{\circ} \mathrm{C}$ prior to their analysis. The pH, electrical conductivity (EC), and $\mathrm{Cu}^{2+}$ concentration in the SPW samples were determined using electrodes (Hanna instruments, pH 210, combined electrode $\mathrm{Ag} / \mathrm{AgCl}-34$, Tetracon $325 \mathrm{WTW}$, and Cupric ion electrode, Fischer Bioblock, USA), respectively. Aluminum, B, Ca, Cu, Fe, Mg, Mn, P, K, $\mathrm{Na}$, and Zn were analyzed by ICP-OES (Varian Liberty 200). Dissolved organic carbon (DOC) in SPW samples was analyzed with a Shimadzu@ TOC 5000A carbon analyzer. The measurement accuracy was checked by performing calibration with a standard reference solution of potassium hydrogen phthalate (KHP) at a concentration of $1000 \mathrm{mg} \mathrm{C} \mathrm{L}^{-1}$. Four DOC measures were performed for each SPW solution. The SPW composition was compared to previous values reported by Oustriere et al. (2016a) for the same unplanted soil treatments 3 months after soil amendment.

\subsection{Statistical analysis}

Influence of soil treatments on SPW parameters, shoot DW yields, shoot ionome and element removals were tested using one-way analysis of variance (ANOVAs). Shoot DW yields and shoot ionome of both plants were tested separately. Normality and homoscedasticity of residuals were met for all tests. When significant differences occurred between treatments, multiple comparisons of mean values were made using post-hoc Tukey HSD tests. Differences were considered 
statistically significant at $\mathrm{p}<0.05$. When element concentrations were below the detection limits in the Unt samples, influence of soil treatments were not statistically tested. All statistical analyses were performed using R software (version 3.0.3, Foundation for Statistical computing, Vienna, Austria).

\section{Results}

\subsection{Soil pore water}

\subsection{1. $\mathrm{pH}, \mathrm{EC}$ and nutrient concentrations}

The Unt soil has a neutral SPW pH (Table 3). At month 3, biochar alone (B) and combined with iron grit (BZ) significantly increased the SPW pH (i.e. $7.3 \pm 0.08$ and $7.6 \pm 0.05$, respectively) and decreased the SPW EC ( $\mu \mathrm{cm}^{-1}$ ) albeit not significantly (i.e. $483 \pm 51$ and $477 \pm 110$ respectively). At month 22 with $A$. donax, the SPW pH and EC rose significantly in all soil treatments from $6.9 \pm 0.1$ (Unt) to $8.1 \pm 0.2$ (AdBZ) for the $\mathrm{pH}$ and from $1024 \pm 117$ (Unt) to $2037 \pm$ 284 (AdBZ) for the EC. In the Pn and PnBZ treatments, the SPW pH did not differ from that of the Unt soil whereas it remained higher in the $P n B$ soil (i.e. $7.5 \pm 0.06$ ). The SPW EC increased in the PnB soil (Month 22) as compared to the B soil (Month 3).

The SPW Ca concentration decreased in the B and BZ soils at month 3 and in all planted soils at month 22 as compared with the Unt soil. The SPW Fe and P concentrations remained below their detection limit, except for P in the B soil. At month 3, the SPW K concentration increased in the B and BZ soils but it decreased at month 22 for both plant species in all soils, and the SPW Mg concentration as well. The SPW Na concentration was significantly lower in the soils planted with A. donax as compared with the Unt soil.

\subsubsection{DOM, Cu and $\mathrm{Cu}^{2+}$}

The DOM concentration in the SPW peaked in all soils cultivated with A. donax, being 3-5 fold higher than in the Unt soil (Fig. $1 \mathrm{~A}, \mathrm{~B}$ and $\mathrm{C})$. In the $P n$ and $P n B$ soils, the DOM increased significantly, i.e. $\left(\mathrm{mg} \mathrm{L}^{-1}\right) 24 \pm 7(\mathrm{Pn})$ and $23 \pm 2(\mathrm{PnB})$ relative to the Unt soil (13 \pm 4). Total $\mathrm{Cu}$ concentration in the SPW $\left(\mathrm{mg} \mathrm{L}^{-1}\right)$ peaked in the $\mathrm{Ad}$ and $A d B$ soils (i.e. $0.53 \pm 0.18$ and $0.68 \pm 0.26$, respectively) as compared to the Unt soil (i.e. $0.22 \pm 0.05$ ). Conversely, adding Z into the Unt soil significantly decreased the SPW total Cu concentration only in the $A d B Z$ soil relative to $A d$ and $A d B$. All treatments, except the $P n$ soil, significantly decreased the SPW $\mathrm{Cu}^{2+}$ concentration $\left(\mathrm{mg} \mathrm{L}^{-1}\right)$ as compared to the Unt soil (i.e. $14.9 \pm 5.3$ ).

\subsection{Plants}

\subsubsection{Plant growth parameters}

At month 22, the root and shoot DW yields of $P$. nigra and $A$. donax for the B-and BZ-amended soils did not differ from those for the Unt soil (Fig. $2 \mathrm{~A}$ and $\mathrm{B}$ ). The root DW yields ( $\mathrm{mg} \mathrm{DW}$ plant $^{-1}$ ) ranged from $17 \pm 11$ to $29 \pm 9$ for $P$. nigra and from $57 \pm 12$ to $84 \pm 14$ for A. donax whereas the shoot DW yields ( $\mathrm{mg} \mathrm{DW}$ plant $^{-1}$ ) range from $19 \pm 7$ to $25 \pm 11$ for $P$. nigra and from $22 \pm 4$ to $26 \pm 3$ for A. donax. For A. donax, the shoot DW yield produced at month 10 (Cut 1) was lower than that harvested at month 22 (Cut 2).

\subsubsection{Shoot ionome}

Shoot Cu concentration of $P$. nigra was significantly lower for the PnBZ plants relative to the Pn plants (Table 4). For A. donax, the shoot Cu concentration was significantly higher for the $\mathrm{AdB}$ plants relative to the $\mathrm{Ad}$ plants. Shoot $\mathrm{Cu}$ removal slightly dropped for the $\mathrm{PnBZ}$ plants relative to the $P n$ plants and significantly increased for the $A d B$ plants as compared to the Ad ones, mainly due to changes in shoot $\mathrm{Cu}$ concentration. Shoot $\mathrm{Ca}, \mathrm{Fe}, \mathrm{K}, \mathrm{Mg}, \mathrm{Na}, \mathrm{P}, \mathrm{Zn}$ and Mn concentrations of poplar and Giant reed were globally similar on the amended and untreated soils, except two significant cases: shoot Na concentration was lower for the PnBZ plants relative to the $P n$ ones, and shoot Mn concentration higher for the $A d B Z$ plants as compared to Ad plants. For A. donax, shoot element concentrations for the Cut 1 were globally higher than those for the Cut 2. Only shoot $\mathrm{Na}$ and $\mathrm{Mg}$ concentrations were higher for the Ad and AdBZ plants of Cut 2 relative to plants harvested in Cut 1 (Supplemental material 1).

\section{Discussion}

Due to biogeochemical reactions between soil phases, amendments, and biological organisms, the behavior of chemical elements (e.g. $\mathrm{Cu}$ ) in amended soils may change over time, which is referred as "aging" (Kookana, 2010). Plant rhizodeposition and associated microorganisms may influence soil Cu speciation, especially when cultivated in a longtime basis (Merino et al., 2015). Here, we discuss the aging effect on the efficiency of biochar, alone and combined with iron grit, and how plants and amendments may influence $\mathrm{Cu}(\mathrm{im})$ mobilization and crop productivity for this Cu-contaminated soil from a wood preservation site.

\subsection{Soil pore water}

\subsubsection{Composition at month 3}

At short-term ( 3 months), the $\mathrm{B}$ amendment decreased $\mathrm{Cu}^{2+}$ concentration while the $\mathrm{BZ}$ combination reduced both $\mathrm{Cu}^{2+}$ and $\mathrm{Cu}$

Table 3

Comparison of physico-chemical parameters of soil pore waters, 3 and 22 months after soil amendment.

\begin{tabular}{|c|c|c|c|c|c|c|c|c|c|}
\hline \multirow[t]{2}{*}{ Treatments } & & \multicolumn{2}{|r|}{$\left(\mu \mathrm{S} \mathrm{cm}^{-1}\right)$} & \multicolumn{6}{|c|}{ Nutrients $\left(\mathrm{mg} \mathrm{L}^{-1}\right)$} \\
\hline & & $\mathrm{pH}$ & $\mathrm{EC}$ & $\mathrm{Ca}$ & $\mathrm{Fe}$ & K & $\mathrm{Mg}$ & $\mathrm{Na}$ & $\mathrm{P}$ \\
\hline \multicolumn{10}{|l|}{ SPW: Month 3} \\
\hline Unt & $(n=6)$ & $6.9 \pm 0.1 \mathrm{f}$ & $1024 \pm 117 \mathrm{~cd}$ & $143 \pm 39 a$ & $<0.02$ & $14 \pm 5 b$ & $5 \pm 2 a$ & $12 \pm 3 \mathrm{ab}$ & $<0.2$ \\
\hline B & $(n=3)$ & $7.3 \pm 0.08 \mathrm{def}$ & $483 \pm 51 \mathrm{~d}$ & $59 \pm 5 \mathbf{b}$ & $<0.02$ & $43 \pm 11 \mathbf{a}$ & $3 \pm 0.3 \mathrm{a}$ & $13 \pm 2 \mathrm{a}$ & $0.3 \pm 0.05$ \\
\hline $\mathrm{BZ}$ & $(\mathrm{n}=3)$ & $7.6 \pm 0.05$ bcd & $477 \pm 110 \mathrm{~d}$ & $46 \pm 20 \mathbf{b}$ & $<0.02$ & $53 \pm 16 \mathbf{a}$ & $3 \pm 1 \mathrm{ab}$ & $17 \pm 6 a$ & $<0.2$ \\
\hline \multicolumn{10}{|c|}{ SPW: Month 22} \\
\hline$P n$ & $(n=5)$ & $7.1 \pm 0.1$ ef & $890 \pm 171 \mathrm{~cd}$ & $2.5 \pm 0.5 \mathbf{c}$ & $<0.02$ & $4.1 \pm 0.5 \mathrm{c}$ & $1.1 \pm 0.2 \mathbf{c}$ & $9.7 \pm 1.9 \mathrm{abc}$ & $<0.2$ \\
\hline$P n \mathrm{~B}$ & $(n=5)$ & $7.5 \pm 0.06$ cde & $1299 \pm 118$ bc & $3.4 \pm 0.3 \mathbf{c}$ & $<0.02$ & $6.3 \pm 0.8 \mathrm{bc}$ & $1.4 \pm 0.1 \mathbf{b c}$ & $12.9 \pm 1.1 \mathrm{a}$ & $<0.2$ \\
\hline $\mathrm{PnBZ}$ & $(n=5)$ & $7.2 \pm 0.1 \mathrm{def}$ & $755 \pm 231 \mathrm{~cd}$ & $2.1 \pm 0.6 \mathbf{c}$ & $<0.02$ & $4 \pm 1.1 \mathrm{c}$ & $1.1 \pm 0.2 \mathbf{c}$ & $5.7 \pm 2.8 \mathrm{bcd}$ & $<0.2$ \\
\hline$A d$ & $(n=5)$ & $7.9 \pm 0.2 \mathbf{a b c}$ & $1737 \pm 300 \mathbf{a b}$ & $<0.5$ & $<0.02$ & $1 \pm 0.3 \mathbf{d}$ & $0.8 \pm 0.4 \mathbf{c}$ & $<0.5$ & $<0.2$ \\
\hline$A d \mathrm{~B}$ & $(\mathrm{n}=5)$ & $8.0 \pm 0.3 \mathbf{a b}$ & $1819 \pm 529 \mathbf{a b}$ & $1.1 \pm 0.5 \mathbf{c}$ & $<0.02$ & $1 \pm 0.5$ de & $1.3 \pm 0.2 \mathbf{b c}$ & $3.8 \pm 3.9 \mathbf{c d}$ & $<0.2$ \\
\hline AdBZ & $(n=5)$ & $8.1 \pm 0.2 \mathbf{a}$ & $2037 \pm 284 \mathbf{a}$ & $0.8 \pm 1.1 \mathrm{c}$ & $<0.02$ & $0.5 \pm 0.3 \mathbf{e}$ & $1.1 \pm 0.6 \mathbf{c}$ & $1 \pm 1.5 \mathbf{d}$ & $<0.2$ \\
\hline \multicolumn{2}{|c|}{ Common values in sandy soils (Oustriere et al., 2016b) } & - & - & $143 \pm 66$ & $0.05 \pm 0.01$ & $27 \pm 44$ & $21 \pm 11$ & $63 \pm 12$ & $5 \pm 2$ \\
\hline
\end{tabular}

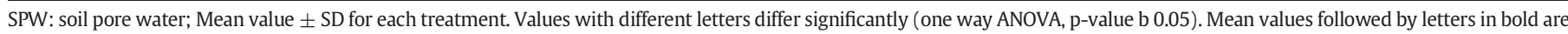
significantly different as compared to the Unt soil. 


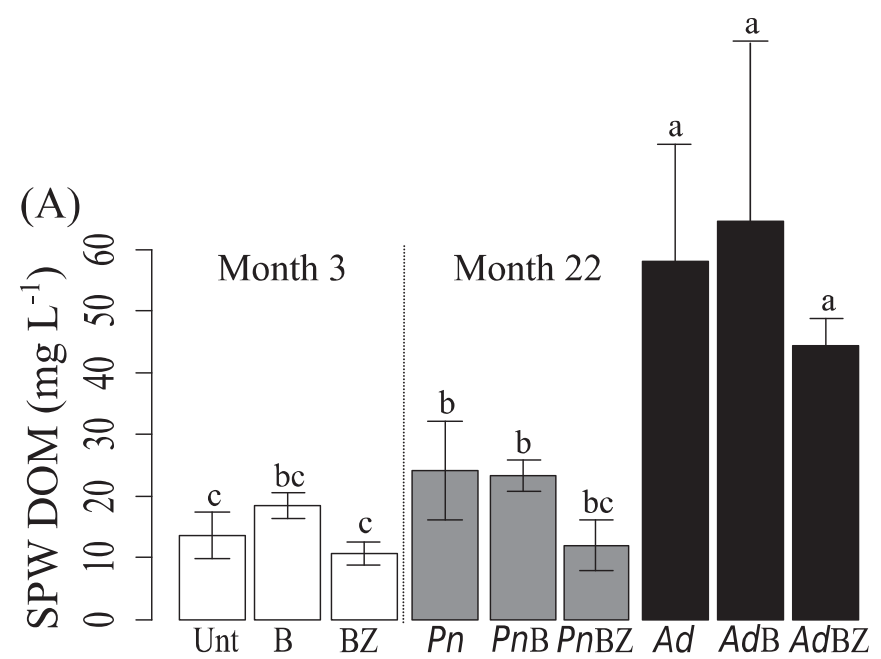

2012). Free $\mathrm{Cu}^{2+}$ may have (1) form inner sphere complexes with the active functional groups of biochar surface in line with SPW pH, (2) precipitate with phosphates and carbonates based on biochar composition (Table 2), and (3) form soluble Cu complexes with DOM increasing total $\mathrm{Cu}$ concentration in the SPW. Adding $\mathrm{Z}$ in combination with $\mathrm{B}$ increase soil $\mathrm{pH}$. In the $\mathrm{BZ}$ treatment, free $\mathrm{Cu}^{2+}$ ions may primarily be sorbed on Fe/Mn oxy-hydroxides, potentially by bidentate inner-sphere complexes with Fe (hydr)oxides (Oustriere et al., 2016a; Tiberg et al., 2016).

\subsubsection{Composition at month 22}

Poplar and aging effect poorly affected $\mathrm{pH}, \mathrm{DOM}$ and total $\mathrm{Cu}$ concentrations in the soil pore water (Table 3; Fig. 1), which agreed with previous studies: $\mathrm{pH}$ and total $\mathrm{Cu}$ in the SPW did not change over 36 months in a poly-contaminated soil at Aznalcázar, South West of Spain, cultivated with Populus alba L. (Ciadamidaro et al., 2013); $\mathrm{pH}$ and total $\mathrm{Cu}$ in the SPW were similar after 5 years in the untreated and compost-amended field plots cultivated with Populus trichocarpa $\times$ deltoides cv. Beaupré at the P7 sub-site (soil contamination with $\mathrm{Cu}$ and PAHs) of this wood preservation site (Mench, unpublished data). Some studies on biochars supported the lack of aging effect on $\mathrm{pH}$ and DOM and total $\mathrm{Cu}$ concentrations in the soil pore water: in a PAHcontaminated soil, soil $\mathrm{pH}$ remained steady after artificial chemical, biological, and physical aging of corn stover residues-derived biochar (Hale et al., 2011). The soil pH was kept between 7.9 and 8.1 over a 3year period in a $(\mathrm{Ni} / \mathrm{Zn})$-contaminated soil, amended by broadleaf hardwood-derived biochar, Castleford, UK, (Shen et al., 2016). After 3 years, SOM and $\left(\mathrm{CaCl}_{2}\right)$-extractable $\mathrm{Cu}$ concentration were stable in a $(\mathrm{Cu} / \mathrm{Cd})$-contaminated soil from a former $\mathrm{Cu}$ mine, amended by cornstraw-derived biochar (Li et al., 2016). At month 22, the SPW Cu${ }^{2+}$ concentration increased in the $\mathrm{PnB}$ and $\mathrm{PnBZ}$ soils as compared to the $\mathrm{B}$ and BZ ones (at month 3) (Fig. 2). This might be explained by: (1) less potential precipitation with phosphates in line with lower SPW P concentration in the Pn soil than in the B one, and (2) decrease of the sorption capacity of biochar over the time (Martin et al., 2012). Rozada et al. (2008) suggested that $\mathrm{Cu}^{2+}$ sorption on biochar surface was easily reversible. When biochar aged, the proportion of oxygen-containing acidic functional groups (e.g., $\mathrm{COO}^{-}, \mathrm{COH}$ and $\mathrm{OH}$ ) increases on the biochar surface, while carboxyl groups slightly decrease (Nguyen and Lehmann, 2009; Guo et al., 2014), contributing to the negative charge of the biochar. Their association with cations (i.e. $\mathrm{Ca}, \mathrm{K}$ and $\mathrm{Mg}$ ), in line with the low SPW cation concentrations (Table 3), and strong affinity for water and DOM may decrease the sorption capacity of biochar for free $\mathrm{Cu}^{2+}$ (Li et al., 2016). In addition, gradual coating and interactions with OM and inorganic phases (Sorrenti et al., 2016) and microbial colonization may decrease the reactivity of the biochar surface. After 4 years, aging increased biochar skeletal density and reduced the water imbibition rate within fragments as a consequence of partial pore clogging (Sorrenti et al., 2016). The cation exchange capacity (CEC) and adsorption capacity of $\mathrm{Cu}$ (II) on the aged biochar were smaller than those of new biochar in a 300 day incubation time pot experiment (Guo et al., 2014). Here, aged biochar particles after cultivation could be further retrieved from the amended soils to assess their composition and reactivity and evidence the main mechanisms.

Enhanced SPW pH and DOM concentration in all amended soils planted with $A$. donax (Table 3; Fig. 1) agreed with an increase in soil $\mathrm{pH}$ (5-9\%) after a 3-month cultivation of $A$. donax on red mudcontaminated soil (Alshaal et al., 2013). Change in SPW pH may partly result from root activity, imbalance uptake of anions (e.g. $\mathrm{NO}_{3}^{-}$) vs. cations increasing the rhizosphere $\mathrm{pH}$ in the basal root zone (Hinsinger et al., 2003; Bravin et al., 2009; Qasim et al., 2016). Calcium uptake by plant, in line with low SPW Ca concentration (Table 3), may initiate a further cation desorption from the solid phase, promote $\mathrm{H}^{+}$sorption and increase soil $\mathrm{pH}$. In addition, increased SPW pH may be related to the higher SPW DOM concentration (Fig. 1; Zhang et al., 2014), which was previously reported in soils cultivated with $A$. donax (Riffaldi et al., 2010). DOM may originate from decayed plant litter, microbial

concentrations in the soil pore water (Oustriere et al., 2016a). In the B soils, the decreased SPW Cu${ }^{2+}$ concentrations were associated with increased soil pH and SPW P and DOM concentrations and decreased SPW Ca concentrations. Based on X-ray absorption fine structure spectroscopy (XAFS), $\mathrm{Cu}^{2+}$ sorption onto biochar is pH dependent (Ippolito et al.,

py (XAFS), Cu'

Fig. 1. (A) DOM, (B) total $\mathrm{Cu}$ and (C) $\mathrm{Cu}^{2+}$ concentrations in the soil pore water; $\mathrm{Cu}$ contaminated soil (Unt, white), amended with either biochar (B) or biochar plus iron donax (Ad, black), alone and amended with either biochar ( $P n \mathrm{~B}$ and $A d B)$ or biochar plus iron grit (PnBZ and $A d B Z)$. Mean values per treatment $(n=5$, Unt: $n=6)$. Values with different letters differ significantly (one way ANOVA, p-value $<0.05$ ). 


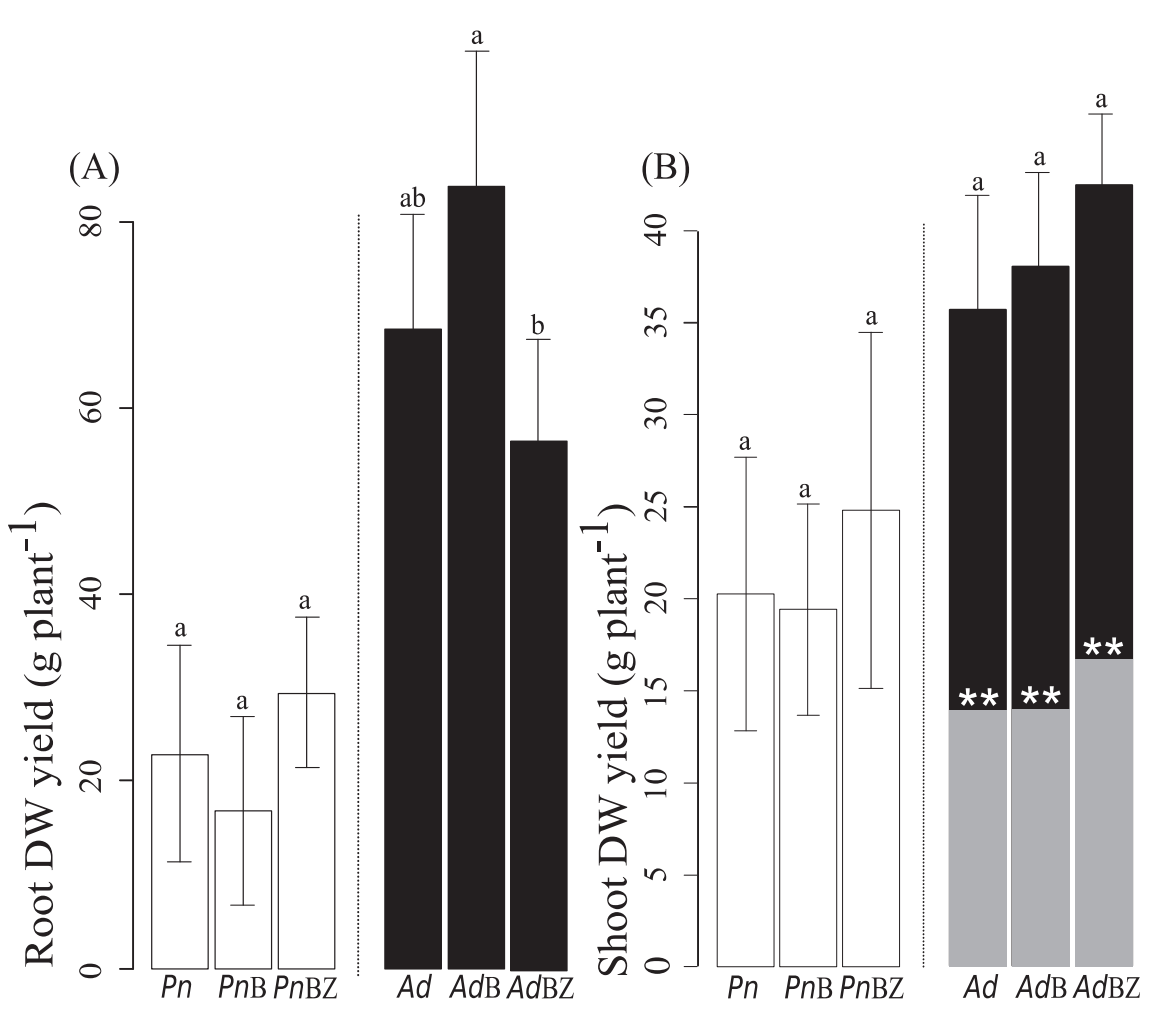

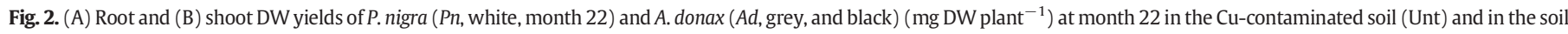

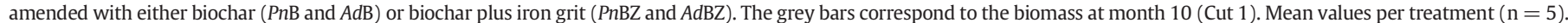
Values with different letters differ significantly (one way ANOVA, p-value $<0.05$ ).

and root depositions, and hydrolysis of insoluble SOM (Haynes, 2005). No leachate from plant litter was produced here as shoots were harvested, but $A$. donax formed a dense mat of roots and rhizomes in the soil (Fig. 2). Giant reed rhizodeposition can highly contribute to SOM available for microbial activity and the DOM pool (Cattaneo et al., 2014; Nsanganwimana et al., 2014; Monti and Zegada-Lizarazu, 2016). Enhanced microbial activity may stimulate both the degradation of SOM and production of microbial DOM (Kiikkilä et al., 2012; Hagedorn et al., 2015). In A. donax cultivated soil, $\mathrm{pH}$ increased between $7.9 \pm$ $0.2(\mathrm{Ad})$ and $8.1 \pm 0.2(\mathrm{AdBZ})$ as compared to the Unt soil (i.e. $6.9 \pm$ 0.1 ), which may promote DOM solubilization (Fang et al., 2016). At month 22, the SPW Cu concentration increased in the Ad and AdB soils as compared to the B and BZ ones (at month 3) (Fig. 2). Enhanced DOM concentration may form soluble complexes with $\mathrm{Cu}$ and increase its SPW concentration (Beesley et al., 2010; Karami et al., 2011). Here,
Giant reed-derived-DOM may act as competitive ligands preventing $\mathrm{Cu}$ retention on biochar surfaces (Beesley et al., 2014). In parallel, with aging, negative charges on biochar surface may form direct or indirect surface complexes with soil components. In addition, coating of DOM may gradually mask sorptive surfaces, thus limiting Cu sorption (Pignatello et al., 2006).

In contrast, the SPW $\mathrm{Cu}^{2+}$ and $\mathrm{Cu}$ concentrations in the AdBZ and $P n B Z$ soils were lower than in the untreated and biochar-amendedsoils cultivated with $A$. donax and P. nigra, albeit not significantly for $\mathrm{Cu}^{2+}$ as compared to $\mathrm{AdB}$ and $\mathrm{PnB}$. The SPW Cu${ }^{2+}$ and $\mathrm{Cu}$ concentrations in the AdBZ and PnBZ soils at month 22 were as low as in the BZ soil at month 3 after soil amendment, albeit not significantly for $\mathrm{Cu}^{2+}$ in the $\mathrm{AdBZ}$ soil. Cationic metal species such as $\mathrm{Cu}^{2+}$ or DOM-Cu complex have high affinity for Fe oxides and can sorb on the newly formed Fe and Mn oxy-hydroxides after Z corrosion in the soil (Kumpiene et al.,

Table 4

Shoot ionome and shoot Cu removal of P. nigra and A. donax at month $22(\mathrm{n}=5)$.

\begin{tabular}{|c|c|c|c|c|c|c|c|c|c|c|}
\hline \multirow[t]{2}{*}{ Treatment } & \multicolumn{2}{|l|}{$\mathrm{Cu}$} & \multicolumn{6}{|c|}{ Shoot nutrient concentrations ( $\mathrm{g} \mathrm{kg}^{-1}$ ) } & \multicolumn{2}{|c|}{$\begin{array}{l}\text { Shoot metal } \\
\text { concentrations }\left(\mathrm{mg} \mathrm{kg}^{-1}\right)\end{array}$} \\
\hline & $\begin{array}{l}\text { Shoot } \mathrm{Cu} \\
\text { concentration } \\
\left(\mathrm{mg} \mathrm{kg}^{-1} \mathrm{DW}\right) \\
\end{array}$ & $\begin{array}{l}\text { Shoot } \mathrm{Cu} \\
\text { removal } \\
\left(\mu \text { plant }^{-1}\right) \\
\end{array}$ & Ca & $\mathrm{Fe}$ & $\mathbf{K}$ & Mg & $\mathrm{Na}$ & $\mathbf{P}$ & Zn & Mn \\
\hline$P n$ & $5.1 \pm 0.7 \mathrm{a}$ & $2.6 \pm 0.4 \mathrm{a}$ & $5.3 \pm 1.1 \mathrm{a}$ & $0.019 \pm 0.005 \mathrm{a}$ & $5.8 \pm 0.3 \mathrm{a}$ & $0.87 \pm 0.21 \mathrm{a}$ & $1.06 \pm 0.28 \mathrm{a}$ & $1.24 \pm 0.48 \mathrm{a}$ & $25 \pm 6 a$ & $8 \pm 2 \mathrm{a}$ \\
\hline$P n \mathrm{~B}$ & $4.3 \pm 0.4 \mathrm{ab}$ & $2.2 \pm 0.2 \mathrm{ab}$ & $5.1 \pm 0.9 \mathrm{a}$ & $0.015 \pm 0.002 \mathrm{a}$ & $6.6 \pm 1.1 \mathrm{a}$ & $0.89 \pm 0.12 \mathrm{a}$ & $0.68 \pm 0.29 \mathrm{ab}$ & $1.2 \pm 0.16 \mathrm{a}$ & $25 \pm 8 \mathrm{a}$ & $10.4 \pm 4 \mathrm{a}$ \\
\hline$P n B Z$ & $4.0 \pm 0.5 \mathbf{b}$ & $2.0 \pm 0.2 \mathbf{b}$ & $4.8 \pm 0.9 \mathrm{a}$ & $0.016 \pm 0.003 \mathrm{a}$ & $6.5 \pm 1 \mathrm{a}$ & $0.84 \pm 0.12 \mathrm{a}$ & $0.47 \pm 0.15 \mathbf{b}$ & $1.24 \pm 0.19 \mathrm{a}$ & $32 \pm 6 a$ & $9.8 \pm 2 \mathrm{a}$ \\
\hline Ad & $4.4 \pm 0.7 \mathbf{b}$ & $2.2 \pm 0.4 \mathbf{b}$ & $2.8 \pm 1.6 \mathrm{a}$ & $0.015 \pm 0.003 a$ & $6.1 \pm 1.2 \mathrm{a}$ & $1.49 \pm 0.63 a$ & $0.19 \pm 0.05 a$ & $0.16 \pm 0.03 a$ & $6 \pm 4 a$ & $13 \pm 7 b$ \\
\hline$A d B$ & $7.0 \pm 2 \mathrm{a}$ & $3.5 \pm 1.2 \mathrm{a}$ & $3.2 \pm 0.8 \mathrm{a}$ & $0.016 \pm 0.004 \mathrm{a}$ & $8.3 \pm 1.4 \mathrm{a}$ & $1.68 \pm 0.43 \mathrm{a}$ & $0.25 \pm 0.1 \mathrm{a}$ & $0.25 \pm 0.06 \mathrm{a}$ & $9 \pm 5 a$ & $14 \pm 6 b$ \\
\hline $\mathrm{AdBZ}$ & $5.2 \pm 1 \mathrm{ab}$ & $2.6 \pm 0.5 \mathrm{ab}$ & $3.2 \pm 0.7 \mathrm{a}$ & $0.021 \pm 0.007 \mathrm{a}$ & $8.7 \pm 2.6 \mathrm{a}$ & $1.77 \pm 0.28 \mathrm{a}$ & $0.2 \pm 0.09 \mathrm{a}$ & $0.19 \pm 0.03 a$ & $7 \pm 5 a$ & $32 \pm 2 \mathrm{a}$ \\
\hline $\begin{array}{l}\text { Common } \\
\text { values }\end{array}$ & $3-20$ & - & $1-50$ & $0.02-0.3$ & $20-50$ & $1.5-3.5$ & - & $1.6-6.0$ & & \\
\hline
\end{tabular}

Mean value \pm SD for each treatment. Values with different letters differ significantly (one way ANOVA, p-value $<0.05$ ). Letters in bold indicated significant differences.

* (Tremel-Schaub and Feix,2005). 
2008; Komárek et al., 2013). The sorption of Cu on Fe and Mn oxyhydroxides is $\mathrm{pH}$-dependent with stronger sorption at high $\mathrm{pH}$. The additional liming effect of biochar can favor the net negative surface charge of Fe and Mn oxy-hydroxides and enhance $\mathrm{Cu}$ sorption. Tiberg et al. (2016) investigated Cu-contaminated soils collected in untreated and $Z$-treated plots at our sampling sub-site after 6 years: the bound $\mathrm{Cu}$ was primarily associated to SOM in the Unt soil whereas with Z addition and increased soil $\mathrm{pH}, \mathrm{Cu}$ sorption shifted towards metal (hydr)oxides. Based on the Cu-ferrihydrite EXAFS spectrum, $\mathrm{Cu}$ was found to primarily bind as inner-sphere bidentate complexes with iron (hydr)oxide (Tiberg et al., 2016).

\subsection{Plants}

At month 3, this biochar alone and combined with iron grit did not promote the root and shoot yields of dwarf beans (Oustriere et al., 2016a). At month 22, this result was similar for P. nigra and A. donax (Fig. 2) and agreed with some studies: root and shoot biomass produced by Lolium multiflorum Lam. was unchanged in a ( $\mathrm{Cd}, \mathrm{Zn}$, and $\mathrm{Pb})$-contaminated soil amended with $1 \%$ miscanthus-derived-biochar after 28 days and 56 days (Houben et al., 2013). After 2 years, grain yields and biomass of wheat were not affected by both rate 10 and $40 \mathrm{tha}^{-1}$ of wheat straw-derived biochar addition in a Cd contaminated paddy soil (Cui et al., 2012). Germination of grass (mix of Festuca rubra L. and Lolium perenne L.) on site failed in a 3-year field experiment on a contaminated $(\mathrm{Ni} / \mathrm{Zn})$ soil amended with broad leaf hardwoodderived biochar (Shen et al., 2016). Here, despite HSN supply, Ca, Fe, $\mathrm{K}, \mathrm{Mg}$ and $\mathrm{P}$ sub-deficiencies might be suggested as their concentrations in P. nigra and A. donax shoots were below or in the low ranges as compared to common values (Tremel-Schaub and Feix, 2005, Table 4). At month 22, Ca, Fe, $\mathrm{K}, \mathrm{Mg}$ and P concentrations in the SPW were low as compared to common values in sandy soil (Table 3 ), likely due to (1) reaction with soil and amendment phases (Cheng et al., 2014), and (2) root uptake. Nutrient concentrations in A. donax shoot even decreased between the Cut 1 and the Cut 2 (Supplemental material 1). It may reflect a dilution effect as shoot DW yield increased. The shoot Cu concentrations of $P$. nigra and $A$. donax $\left(\mathrm{mg} \mathrm{kg}^{-1}\right)$ were similar across the treatments, ranging from $4.0 \pm 0.5(\mathrm{PnBZ})$ to $7.0 \pm 2$ (AdBZ) (Table 4), and in the range of common values (3-20 $\mathrm{mg} \mathrm{kg}^{-1}$, TremelSchaub and Feix, 2005). Stem and foliar Cu concentrations $\left(\mathrm{mg} \mathrm{kg}^{-1}\right)$ reached 3.21 and 7.17 for $A$. donax on a poly-contaminated urban stream (Bonanno et al., 2013). Shoot $\mathrm{Cu}$ concentration ranged between 7 and $17 \mathrm{mg} \mathrm{kg}^{-1}$ in $P$. alba grown for 3 years in a Cu-contaminated soil (Ciadamidaro et al., 2013). Giant reed and poplars are Cu excluders accumulating $\mathrm{Cu}$ in their roots, which may explain their low shoot $\mathrm{Cu}$ concentration (Kabata-Pendias, 2001; Bonanno et al., 2013; Ciadamidaro et al., 2013; Elhawat et al., 2014).

\subsection{Practical implication}

Effect of plant species: Giant reed was more efficient than P. nigra to decrease $\mathrm{Cu}^{2+}$ exposure in its rhizosphere but increased total $\mathrm{Cu}$ concentration in the soil pore water, which may potentially enhance $\mathrm{Cu}$ leaching from the root zone (Fig. 1). After 2 years, $P$. nigra did not contribute to $\mathrm{Cu}$ immobilization (Fig. 1). Without soil amendment, both plant species were unable to stabilize $\mathrm{Cu}$ in excess.

Effect of soil amendment: combining iron grit with biochar promoted $\mathrm{Cu}$ stabilization but not the growth of $A$. donax and $P$. nigra. An additional fertilization may be required. Long-term field plots must investigate the sustainability of $\mathrm{Cu}$ stabilization, biomass production of non-food crops and the life cycling of such phytomanagement option.

\section{Conclusion}

After a 22-month reaction period, the SPW $\mathrm{Cu}^{2+}$ concentration increased again in the $\mathrm{B}$ and $\mathrm{BZ}$ soils cultivated with $P$. nigra as compared to its value at month 3. Cultivation of A. donax incremented the DOM concentration in the soil pore water. Such high SPW DOM concentration in the Giant reed-planted soils, which may induce the formation of $\mathrm{Cu}-$ DOM complexes, matched with a decrease of $\mathrm{Cu}^{2+}$ concentration but increased total $\mathrm{Cu}$ concentration in the soil pore water. Iron grit with biochar was more effective to stabilize soil Cu than biochar alone with both A. donax and P. nigra cultivation. Biochar alone and combined with iron grit did not promote the root and shoot yields of $A$. donax and $P$. nigra as compared to the untreated soil but the shoot $\mathrm{Cu}$ concentrations were in the common ranges for both plants.

Supplementary data to this article can be found online at http://dx. doi.org/10.1016/j.scitotenv.2016.11.048.

\section{Acknowledgements}

This work was supported by ADEME (French Agency for the Environment and Energy, PhD grant no 2013-ID5081 of N. Oustrière), the French National Research Agency (ANR CD2I, program PHYTOCHEM) and the ERA-Net FACCE SURPLUS (project INTENSE, no ANR-15-SUSF0007-06; http://faccesurplus.org/research-projects/intense/). The UMR Biogeco is a member of the INRA Ecotoxicologist network, ECOTOX.

\section{References}

Alshaal, T., Domokos-Szabolcsy, E., Márton, L., Czakó, M., Kátai, J., Balogh, P., Elhawat, N., El-Ramady, H., Fari, M., 2013. Phytoremediation of bauxite-derived red mud by giant reed. Environ. Chem. Lett. 11:295-302. http://dx.doi.org/10.1007/s10311-0130406-6.

Baize, D., 2000. Guide des analyses en pédologie. second ed. 257. INRA Éditions, Paris, France.

Bakshi, S., He, Z.L., Harris, W.G., 2014. Biochar amendment affects leaching potential of copper and nutrient release behavior in contaminated sandy soils. J. Environ. Qual. 43:1894-1902. http://dx.doi.org/10.2134/jeq2014.05.0213.

Beesley, L., Marmiroli, M., 2011. The immobilisation and retention of soluble arsenic, cadmium and zinc by biochar. Environ. Pollut. 159:474-480. http://dx.doi.org/10. 1016/j.envpol.2010.10.016.

Beesley, L., Moreno-Jimenez, E., Gomez-Eyles, J.L., 2010. Effects of biochar and greenwaste compost amendments on mobility, bioavailability and toxicity of inorganic and organic contaminants in a multi-element polluted soil. Environ. Pollut. 158: 2282-2287. http://dx.doi.org/10.1016/j.envpol.2010.02.003.

Beesley, L., Moreno-Jiménez, E., Gomez-Eyles, J.L., Harris, E., Robinson, B., Sizmur, T., 2011. A review of biochars' potential role in the remediation, revegetation and restoration of contaminated soils. Environ. Pollut. 159:3269-3282. http://dx.doi.org/10.1016/j. envpol.2011.07.023.

Beesley, L., Inneh, O.S., Norton, G.J., Moreno-Jimenez, E., Pardo, T., Clemente, R., Dawson, J.J.C., 2014. Assessing the influence of compost and biochar amendments on the mobility and toxicity of metals and arsenic in a naturally contaminated mine soil. Environ. Pollut. 186:195-202. http://dx.doi.org/10.1016/j.envpol.2013.11.026.

Bes, C., Mench, M., 2008. Remediation of copper-contaminated topsoils from a wood treatment facility using in situ stabilization. Environ. Pollut. 156:1128-1138. http://dx.doi.org/10.1016/j.envpol.2008.04.006.

Bian, R., Joseph, S., Cui, L., Pan, G., Li, L., Liu, X., Zhang, A., Rutlidg, H., Wong, S., Chia, C., Marjo, C., Gong, B., Munroe, P., Donne, S., 2014. A three-year experiment confirms continuous immobilization of cadmium and lead in contaminated paddy field with biochar amendment. J. Hazard. Mater. 272:121-128. http://dx.doi.org/10.1016/j. jhazmat.2014.03.017.

Bolan, N.S., Adriano, D.C., Mahimairaja, S., 2014. Distribution and bioavailability of trace elements in livestock and poultry manure by-products. Crit. Rev. Environ. Sci. Technol. 34:291-338. http://dx.doi.org/10.1080/10643380490434128.

Bonanno, G., Cirelli, G.L., Toscano, A., Lo Giudice, R., Pavone, P., 2013. Heavy metal content in ash of energy crops growing in sewage-contaminated natural wetlands: potential applications in agriculture and forestry? Sci. Total Environ. 452-453:349-354. http:// dx.doi.org/10.1016/j.scitotenv.2013.02.048.

Bravin, M.N., Marti, A.L., Clairotte, M., Hinsinger, P., 2009. Rhizosphere alkalisation - a major driver of copper bioavailability over a broad $\mathrm{pH}$ range in an acidic, coppercontaminated soil. Plant Soil 318:257-268. http://dx.doi.org/10.1007/s11104-0089835-6.

Bridgwater, T., 2006. Biomass for energy. J. Sci. Food Agric. 86:1755-1768. http://dx.doi. org/10.1002/jsfa.2605.

Calfapietra, C., Gielen, B., Karnosky, D., Ceulemans, R., Scarascia Mugnozza, G., 2010. Response and potential of agroforestry crops under global change. Environ. Pollut. 158:1095-1104. http://dx.doi.org/10.1016/j.envpol.2009.09.008.

Cattaneo, F., Barbanti, L., Gioacchini, P., Ciavatta, C., Marzadori, C., 2014. 13C abundance shows effective soil carbon sequestration in Miscanthus and giant reed compared to arable crops under Mediterranean climate. Biol. Fertil. Soils 50:1121-1128. http://dx.doi.org/10.1007/s00374-014-0931-X.

Cheng, C.H., Lin, T.P., Lehmann, J., Fang, L.J., Yang, Y.W., Menyailo, O.V., Chang, K.H., Lai, J.S., 2014. Sorption properties for black carbon (wood char) after long term exposure in soils. Org. Geochem. 70:53-61. http://dx.doi.org/10.1016/j.orggeochem.2014.02.013. 
Ciadamidaro, L., Madejón, E., Puschenreiter, M., Madejón, P., 2013. Growth of Populus alba and its influence on soil trace element availability. Sci. Total Environ. 454-455: 337-347. http://dx.doi.org/10.1016/j.scitotenv.2013.03.032.

Cui, L.Q., Pan, G.X., Li, L.Q., Yan, J.L., Zhang, A., Bian, R.J., Chang, A., 2012. The reduction of wheat $\mathrm{Cd}$ uptake in contaminated soil via biochar amendment: a two-year field experiment. Bioresources 7, 5666-5676.

Cundy, A., Bardos, P., Puschenreiter, M., Witters, N., Mench, M., Bert, V., Friesl-Hanl, W., Muller, I., Weyens, N., Vangronsveld, J., 2015. Developing effective decision support for the application of "gentle" remediation options: the GREENLAND project. Remediat. J. 25:101-114. http://dx.doi.org/10.1002/rem.21435.

Elhawat, N., Alshaal, T., Domokos-Szabolcsy, E., El-Ramady, H., Márton, L., Czakó, M., Kátai J., Balogh, P., Sztrik, A., Molnár, M., Popp, J., Fári, M.G., 2014. Phytoaccumulation potentials of two biotechnologically propagated ecotypes of Arundo donax in copper-contaminated synthetic wastewater. Environ. Sci. Pollut. Res. 21:7773-7780. http://dx.doi.org/10.1007/s11356-014-2736-8.

Elhawat, N., Alshaal, T., Domokos-Szabolcsy, E., El-Ramady, H., Antal, G., Márton, L., Czakó, M., Balogh, P., Fári, M.G., 2015. Copper uptake efficiency and its distribution within bioenergy grass giant reed. Bull. Environ. Contam. Toxicol. 95:452-458. http://dx. doi.org/10.1007/s00128-015-1622-5.

Evangelou, M.W.H., Deram, A., Gogos, A., Studer, B., Schulin, R., 2012. Assessment of suitability of tree species for the production of biomass on trace element contaminated soils. J. Hazard. Mater. 209-210:233-239. http://dx.doi.org/10.1016/j.jhazmat.2012. 01.008 .

Fang, W., Wie, Y., Liu, J., 2016. Comparative characterization of sewage sludge compost and soil: heavy metal leaching characteristics. J. Hazard. Mater. 310:1-10. http://dx. doi.org/10.1016/j.jhazmat.2016.02.025.

Gonsalvesh, L., Yperman, J., Carleer, R., Mench, M., Herzig, R., Vangronsveld, J., 2016. Valorisation of heavy metals enriched tobacco biomass through slow pyrolysis and steam activation. J. Chem. Technol. Biotechnol. 91:1585-1595. http://dx.doi.org/10. $1002 /$ jctb.4889.

Guo, Y., Tang, W., Wu, J., Huang, Z., Dai, J., 2014. Mechanism of Cu(II) adsorption inhibition on biochar by ist aging process. J. Environ. Sci. 26:2123-2130. http://dx.doi.org/10. 1016/j.jes.2014.08.012.

Hagedorn, F., Bruderhofer, N., Ferrari, A., Niklaus, P.A., 2015. Tracking litter-derived dissolved organic matter along a soil chronosequence using 14C imaging: biodegradation, physico-chemical retention or preferential flow? Soil Biol. Biochem. 88: 333-343. http://dx.doi.org/10.1016/j.soilbio.2015.06.014.

Hale, S., Hanley, K., Lehmann, J., Zimmerman, A.R., Cornelissen, G., 2011. Effects of chemical, biological, and physical aging as well as soil addition on the sorption of pyrene to activated carbon and biochar. Environ. Sci. Technol. 45:10445-10453. http://dx.doi. org/10.1021/es202970x.

Haynes, R.J., 2005. Labile organic matter fractions as central components of the quality of agricultural soils: an overview. Adv. Agron. 85:221-268. http://dx.doi.org/10.1016/ S0065-2113(04)85005-3.

Hinsinger, P., Plassard, C., Tang, C., Jaillard, B., 2003. Origins of root-mediated pH changes in the rhizosphere and their responses to environmental constraints: a review. Plant Soil 248:43-59. http://dx.doi.org/10.1023/A:1022371130939.

Houben, D., Evrard, L., Sonnet, P., 2013. Mobility, bioavailability and pH-dependent leaching of cadmium, zinc and lead in a contaminated soil amended with biochar. Chemosphere 92:1450-1457. http://dx.doi.org/10.1016/j.chemosphere.2013.03.055.

Ippolito, J.A., Strawn, D.G., Scheckel, K.G., Novak, J.M., Ahmedena, M., Niandou, M.A.S., 2012. Macroscopic and molecular investigations of copper sorption by a steam activated biochar. J. Environ. Qual. 41:150-156. http://dx.doi.org/10.2134/jeq2011.0113.

Kabata-Pendias, A., 2001. Trace Elements in Soils and Plants. third ed. CRC Press, Inc., Boca Raton, Florida.

Karami, N., Clemente, R., Moreno-Jimenez, E., Lepp, N.W., Beesley, L., 2011. Efficiency of green waste compost and biochar soil amendments for reducing lead and copper mobility and uptake to ryegrass. J. Hazard. Mater. 191:41-48. http://dx.doi.org/10.1016/ j.jhazmat.2011.04.025

Kidd, P., Mench, M., Álvarez-Lopez, V., Bert, V., Dimitriou, I., Friesl-Hanl, W., Herzig, R., Janssen, J.O., Kolbas, A., Müller, I., Neu, S., Renella, G., Ruttens, A., Vangronsveld, J., Puschenreiter, M., 2015. Agronomic practices for improving gentle remediation of trace element-contaminated soils. Int. J. Phytorem. 17:1005-1037. http://dx.doi.org/ 10.1080/15226514.2014.1003788.

Kiikkilä, O., Kitunen, V., Spetz, P., Smolander, A., 2012. Characterization of dissolved organic matter in decomposing Norway spruce and silver birch litter. Eur. J. Soil Sci. 63:476-486. http://dx.doi.org/10.1111/j.1365-2389.2012.01457.x.

Komárek, M., Vanek, A., Ettler, V., 2013. Chemical stabilization of metals and arsenic in contaminated soils using oxides. A review. Environ. Pollut. 172:9-22. http://dx.doi. org/10.1016/j.envpol.2012.07.045.

Kookana, R.S., 2010. The role of biochar in modifying the environmental fate, bioavailability, and efficacy of pesticides in soils: a review. Aust. J. Soil Res. 48:627-637. http://dx. doi.org/10.1071/SR10007.

Kumpiene, J., Lagerkvist, A., Maurice, C., 2008. Stabilization of $\mathrm{As}, \mathrm{Cr}, \mathrm{Cu}, \mathrm{Pb}$ and $\mathrm{Zn}$ in soil using amendments - a review. Waste Manag. 28:215-225. http://dx.doi.org/10.1016/ j.wasman.2006.12.012

Kumpiene, J., Mench, M., Bes, C.M., Fitts, J.P., 2011. Assessment of aided phytostabilization of copper-contaminated soil by X-ray absorption spectroscopy and chemical extractions. Environ. Pollut. 159:1536-1542. http://dx.doi.org/10.1016/j.envpol.2011.03.005.

Li, H., Ye, X., Geng, Z., Zhou, H., Guo, X., Zhang, Y., Zhao, H., Wang, G., 2016. The influence of biochar type on long-term stabilization for $\mathrm{Cd}$ and $\mathrm{Cu}$ in contaminated paddy soils. J. Hazard. Mater. 304:40-48. http://dx.doi.org/10.1016/j.jhazmat.2015.10.048.

Lucas-Borja, M.E., Wic-Baena, C., Moreno, J.L., Dadi, T., García, C., Andrés-Abellá, M., 2011. Microbial activity in soil under fast-growing paulownia (Paulownia elongata $x$ fortunei) plantations in Mediterranean areas. Appl. Soil Ecol. 51:42-51. http://dx. doi.org/10.1016/j.apsoil.2011.08.011.
M., D'agosta, G.M., Copani, V., Patanè, C., Cosentino, S.L, 2009. Biomass yield and energy balance of three perennial crops for energy use in the semi-arid Mediterranean environment. Field Crop Res. 114 (2):204-213. http://dx.doi.org/10. 1016/j.fcr.2009.07.020.

Marchand, L., Nsanganwimana, F., Gonnelli, C., Colzi, I., Fletcher, T., Oustriere, N., Kolbas, A., Kidd, P., Bordas, F., Newell, P., Alvarenga, P., Lamy, J.B., Deletic, A., Mench, M. 2014. Intra-specific variability versus constitutive-like tolerance to face $\mathrm{Cu}$ exposure in populations of six rooted macrophytes. Environ. Pollut. 193:205-215. http://dx. doi.org/10.1016/j.envpol.2014.07.001.

Martin, S.M., Kookana, R.S., Van Zwieten, L., Krull, E., 2012. Marked changes in herbicide sorption-desorption upon ageing of biochars in soil. J. Hazard. Mater. 231-232: 70-78. http://dx.doi.org/10.1016/j.jhazmat.2012.06.040.

Mench, M., Bes, C., 2009. Assessment of ecotoxicity of topsoils from a wood treatment site. Pedosphere 19 (2):143-155. http://dx.doi.org/10.1016/S1002-0160(09)60104-1.

Merino, C., Nannipieri, P., Matus, F., 2015. Soil carbon controlled by plant, microorganism and mineralogy interactions. J. Soil Sci. Plant Nutr. 15 (2), 321-332.

Mola-Yudego, B., Díaz-Yáñez, O., Dimitriou, I., 2015. How much yield should we expect from fast-growing plantations for energy? Divergences between experiments and commercial willow plantations. Bioenergy Res. 8 (4). http://dx.doi.org/10.1007/ s12155-015-9630-1.

Monti, A., Zegada-Lizarazu, W., 2016. Sixteen-year biomass yield and soil carbon storage of giant reed (Arundo donax L.) grown under variable nitrogen fertilization rates. Bioenergy Res. 9:248-256. http://dx.doi.org/10.1007/s12155-015-9685-z.

Nagodavithane, C.L., Singh, B., Fang, Y., 2014. Effect of ageing on surface charge characteristics and adsorption behaviour of cadmium and arsenate in two contrasting soils amended with biochar. Soil Res. 52:155-163. http://dx.doi.org/10.1071/SR13187.

Nguyen, B.T., Lehmann, J., 2009. Black carbon decomposition under varying water regimes. Org. Geochem. 40:846-853. http://dx.doi.org/10.1016/j.orggeochem.2009.05.004.

Nsanganwimana, F., Marchand, L., Douay, F., Mench, M., 2014. Arundo donax L., a candidate for phytomanaging water and soils contaminated by trace elements and producing plant-based feedstock, a review. Int. J. Phytorem. 16:982-1017. http://dx.doi.org/ 10.1080/15226514.2013.810580

Oustriere, N., Marchand, L., Galland, W., Gabon, L., Lottier, N., Motelica, M., Mench, M., 2016a. Influence of biochars, compost and iron grit, singly and in combination, on copper solubility and phytotoxicity in a Cu-contaminated soil from a wood preservation site. Sci. Total Environ. 566-567:816-825. http://dx.doi.org/10.1016/j.scitotenv. 2016.05.091.

Oustriere, N., Marchand, L., Bouchardon, J.L., Faure, O., Moutte, J., Mench, M., 2016b. Aided phytostabilization of a trace element-contaminated technosol developed on steel mill wastes. J. Hazard. Mater. 320:458-468. http://dx.doi.org/10.1016/j.jhazmat.2016.08. 048.

Pignatello, J.J., Kwon, S., Lu, Y., 2006. Effect of natural organic substances on the surface and adsorptive properties of environmental black carbon (char): attenuation of surface activity by humic and fulvic acids. Environ. Sci. Technol. 40:7757-7763. http://dx.doi.org/10.1021/es061307m.

Qasim, B., Motelica-Heino, M., Bourgerie, S., Gauthier, A., Morabito, D., 2016. Rhizosphere effects of Populus euramericana Dorskamp on the mobility of $\mathrm{Zn}, \mathrm{Pb}$ and $\mathrm{Cd}$ in contaminated technosols. J. Soils Sediments 16:811-820. http://dx.doi.org/10.1007/ s11368-015-1270-8.

Riffaldi, R., Saviozzi, A., Cardelli, R., Bulleri, F., Angelini, L., 2010. Comparison of soil organic-matter characteristics under the energy crop giant reed, cropping sequence and natural grass. Commun. Soil Sci. Plan. Nut. 41:173-180. http://dx.doi.org/10. 1080/00103620903426972.

Rozada, F., Otero, M., Morán, A., García, A.I., 2008. Adsorption of heavy metals onto sewage sludge-derived materials. Bioresour. Technol. 99:6332-6338. http://dx.doi.org/ 10.1016/j.biortech.2007.12.015.

Scordia, D., Cosentino, S.L., Lee, J.W., Jeffries, T.W., 2012. Bioconversion of giant reed (Arundo donax L.) hemicelluloses hydrolysate to ethanol by Scheffersomyces stipitis CBS6054. Biomass Bioenergy 39:296-305. http://dx.doi.org/10.1016/j.biombioe. 2012.01.023.

Shen, Z., Md Som, A., Wang, F., Jin, F., McMillan, O., Al-Tabbaa, A., 2016. Long-term impact of biochar on the immobilisation of nickel (II) and zinc (II) and the revegetation of a contaminated site. Sci. Total Environ. 542:771-776. http://dx.doi.org/10.1016/j. scitotenv.2015.10.057.

Sorrenti, G., Masiello, C.A., Dugan, B., Toselli, M., 2016. Biochar physico-chemical properties as affected by environmental exposure. Sci. Total Environ. 563-564:237-246. http://dx.doi.org/10.1016/j.scitotenv.2016.03.245.

Tiberg, C., Kumpiene, J., Gustafsson, J.P., Marsz, A., Persson, I., Mench, M., Kleja, D.B., 2016. Immobilization of $\mathrm{Cu}$ and as in two contaminated soils with zerovalent iron - longterm performance and mechanisms. Appl. Geochem. 67:144-152. http://dx.doi.org/ 10.1016/j.apgeochem.2016.02.009.

Tremel-Schaub, A., Feix, I., 2005. Contamination des Sols - Transferts des Sols vers les Plantes, Agence de l'Environnement et de la Maîtrise de l'Énergie, Angers: EDP Sciences, Les Ulis. p. 106

Villanneau, E., Perry-Giraud, C., Saby, N., Jolivet, C., Marot, F., Maton, D., Floch-Barneaud, A., Antoni, V., Arrouays, D., 2008. Détection de valeurs anomaliques d'éléments traces métalliques dans les sols à l'aide du Réseau de Mesure de la Qualité des Sols. Etude et Gestion des Sols 15 (3), 183-200.

Zhang, X., Wang, H., He, L., Lu, K., Sarmah, A., Li, J., Bolan, N.S., Pei, J., Huang, H., 2013. Using biochar for remediation of soils contaminated with heavy metals and organic pollutants. Environ. Sci. Pollut. Res. 20:8472-8483. http://dx.doi.org/10.1007/s11356-0131659-0.

Zhang, S., Li, T., Zhang, X., Yu, H., Zheng, Z., Wang, Y., Hao, X., Pu, Y., 2014. Changes in pH, dissolved organic matter and $\mathrm{Cd}$ species in the rhizosphere soils of $\mathrm{Cd}$ phytostabilizer Athyrium wardii (Hook.) Makino involved in Cd tolerance and accumulation. Environ. Sci. Pollut. Res. 21:4605-4613. http://dx.doi.org/10.1007/s11356-013-2421-3. 